\title{
Sanksi Hukum Terhadap Pihak Yang Melakukan Wanprestasi Dalam Perjanjian Waralaba Online
}

\section{Oleh :}

Husnaini, SE., SH., MH.

\section{(Dosen Tetap Sekolah Tinggi Ilmu Hukum Sumpah Pemuda)}

\begin{abstract}
ABSTRAK
Perjanjian waralaba merupakan suatu pedoman hukum yang menggariskan tanggung jawab dari pemberi waralaba (yang sering disebut franchisor)dan penerima waralaba(yang sering disebut franchisee).Penerima waralaba ketika setuju untuk usaha waralaba yang ditawarkan kepada dia harus tunduk pada perjanjian yang ada.Hal-hal yang sedemikian hendaknya juga berlaku terhadap waralaba-waralaba on line.

Tanpa adanya perjanjian tertulis, maka sangat berpengaruh terhadap kemungkinan resiko hukum yang terjadi dalam pelaksanaan usaha waralaba online. Dimana salah satu pihak dapat saja melakukan hal-hal yang bisa merugikan kelangsungan usaha mereka sehingga kepastian hukum kepada para pihak sulit tercapai.
\end{abstract}

\begin{abstract}
The franchise agreement is a legal guideline that outlines the responsibilities of the franchisor (which is often called the franchisor) and the franchisee (who is often called the franchisee). The franchisee when agreeing to the franchise offered to him must be subject to the existing agreement. such ones should also apply to online franchises.

Without a written agreement, it is very influential on the possibility of legal risks that occur in the implementation of online franchising. Where one party can do things that can harm the sustainability of their business so that legal certainty to the parties is difficult to achieve.
\end{abstract}

\section{A. Latar belakang}

Dinamika sosial masyarakat di dunia saat ini telah mengalami perubahan pesat, hal ini ditandai oleh perkembangan yang spektakuler di bidang teknologi. Salah satu perkembangan teknologi tersebut diantaranya adalah dengan ditemukannya internet yaitu teknologi yang memungkinkan kita melakukan pertukaran informasi dengan siapapun dan dimanapun orang tersebut berada tanpa dibatasi oleh ruang dan waktu. Setelah internet terbuka bagi masyarakat luas, internet 
mulai digunakan juga untuk kepentingan perdagangan atau bisnis. Setidaknya ada dua hal yang mendorong kegiatan bisnis dalam kaitannya dengan kemajuan teknologi yaitu meningkatnya permintaan atas produk-produk teknologi itu sendiri dan kemudahan untuk melakukan transaksi bisnis. ${ }^{17}$

Beberapa bentuk kerjasama bisnis yang saat ini banyak sekali digunakan di Indonesia, semakin mudah dan banyaknya model bisnis yang ditawarkan, memberikan peluang yang sangat besar bagi para pelaku usaha untuk memulai bahkan memperbesar jaringan usahanya. Beberapa bentuk kerjasama bisnis yang saat ini banyak sekali digunakan di Indonesia,salah satunya waralaba.

Waralaba digambarkan sebagai perpaduan bisnis "besar" dan "kecil" yaitu perpaduan antara energi dan komitmen individual dengan sumber daya dan kekuatan sebuah perusahaan besar

Secara umum, waralaba adalah hak untuk mendistribusikan barang atau jasa kepada konsumen, yang mana hak tersebut diberikan secara langsung oleh pemilik merek kepada individu atau kelompok, yang dalam hal ini disebut sebagai penerima waralaba dengan ketentuan-ketentuan tertentu. ${ }^{18}$

Pengertian waralaba dalam Pasal 1 Ayat (1) Peraturan Pemerintah RI No. 42 Tahun 2007 Tentang Waralaba,adalah : "Hak khusus yang dimiliki oleh orang perorangan atau badan usahaterhadap sistem bisnis dengan ciri khas usaha dalam rangka memasarkan barang dan/atau jasa yang telah terbukti berhasil dan dapat dimanfaatkandan /atau digunakan oleh pihak lain berdasarkan perjanjian waralaba". ${ }^{19}$

Usaha waralaba pada umumnya mengharuskan dilakukan perjanjian, dimana perjanjian yang ada itu adalah perjanjian baku yang dibuat terlebih dahulu oleh pemberi waralaba.perjanjian baku (standar) adalah perjanjian yang diterapkan secara sepihak oleh produsen/pelaku usaha yang mengandung ketentuan yang berlaku umum (massal) sehingga pihak konsumen hanya mempunyai 2 pilihan saja yaitu :

1. Apabila konsumen membutuhkan produk barang dan/atau jasa yang ditawarkan, maka stujuilah perjanjian dengan syarat-syarat baku yang telah ditentukan oleh pelaku usaha (Take I)

\footnotetext{
17 Agus Raharjo, Cybercrime: Pemahaman dan Upaya Pencegahan Kejahatan Berteknologi, PT. Citra Aditya Bakti, Bandung, 2002, hlm.1

${ }^{18}$ Akifa P. Nayla, Komplet Akuntansi Untuk UKM dan Waralaba, Laksana, Yogyakarta ,2014, hlm 148

${ }^{19}$ Lihat Pasal 1 Ayat (1) Peraturan Pemerintah RI No. 42 Tahun 2007 Tentang Waralaba
} 
2. Apabila konsumen tidakmenyetujui syarat-syarat baku ditawarkan oleh pelaku usaha tersebut, maka jangan membuat perjanjian dengan pelaku usaha yang bersangkutan (Leave It) ${ }^{20}$

Ketentuan mengenai klausula baku diatur dalam Pasal 18 ayat (1), (2) dan (3) Undang-Undang tentang Perlindungan Konsumen, yang berbunyi :

1) Pelaku usaha dalam menawarkan barang dan/atau jasa yang ditunjukan untuk di perdagangkan dilarang membuat dan mencantumkan klausula baku pada setiap dokumen dan/atau perjanjian apabila:

a. Menyatakan pengalihan tanggung jawab pelaku usaha,

b. Menyatakan bahwa pelaku usaha berhak menolak penyeraha kembali barang yang di beli konsumen,

c. Menyatakan bahwa pelaku usaha berhak menolak penyerahan kembali uang yang di bayarkan atas barang yang di beli konsumen,

d. Menyatakan pemberian kuasa dari konsumen kepada pelaku usaha baik secara langsung maupun tidak langsung untuk melakukan segala tindakan sepihak yang berkaitan dengan barang yang di beli oleh konsumen secara angsuran,

e. Mengatur perihal pembuktian atas hilangnya kegunaan barang atau pemanfaatan jasa yang dibeli oleh konsumen,

f. Memberikan hak kepada pelaku usaha untuk mengurangi manfaat jasa atau mengurangi harta kekayaan konsumen yang menjadi objek jual beli jasa,

g. Menyatakan tunduknya konsumen kepada peraturan yang berupa aturan baku, tambahan, lanjutan dan/atau penggabungan lanjutan yang dibuat sepihak oleh pelaku usaha dalam masa konsumen memanfaatkan jasa yang di belinya,

h. Menyatakan bahwa konsumen memberi kuasa kepada pelaku usaha untuk pembebanan hak tanggungan, hak gadai, atau hak jaminan terhadap barang yang di beli oleh konsumen secara angsuran.

2) Pelaku usaha dilarang mencantumkan klausula baku yang letak atau bentuknya sulit terlihat atau tidak dapat terbaca secara jelas, atau yang mengungkapkanya sulit dimengerti

\footnotetext{
${ }^{20}$ Az,Nasution Konsumen Dan Hukum,:Pustaka Sinar Harapan, Jakarta, 1999, hlm. 97
} 
3) Setiap klausula baku yang telah di tetapkan oleh pelaku usaha pada dokumen atau perjanjian yang memenuhi ketentauan sebagai dimaksud pada ayat (1) dan ayat (2) dinyatakan batal demi hukum.

Perjanjian waralaba merupakan suatu pedoman hukum yang menggariskan tanggung jawab dari pemberi waralaba (yang sering disebut franchisor)dan penerima waralaba(yang sering disebut franchisee).Penerima waralaba ketika setuju untuk usaha waralaba yang ditawarkan kepada dia harus tunduk pada perjanjian yang ada.Hal-hal yang sedemikian hendaknya juga berlaku terhadap waralaba-waralaba on line.

Rata-rata waralaba online ini adalah waralaba dengan skala kecil, jika ada yang berminat untuk menjalankan usaha ini maka kesepakatan atau perjanjian terjadi hanya lewat media sosial tanpa adanya perjanjian baku antara kedua belah pihak. Mereka tidak saling bertemu bahkan juga tidak ada pelatihan kerja terkait dengan konsep pemasaran. Ketika persetujuan itu ada dan sejumlah uang yang telah dikirmkan maka sejak itulah perjanjian waralaba onine terjadi.

Tanpa adanya perjanjian tertulis, maka sangat berpengaruh terhadap kemungkinan resiko hukum yang terjadi dalam pelaksanaan usaha waralaba online. Dimana salah satu pihak dapat saja melakukan hal-hal yang bisa merugikan kelangnsungan usaha mereka sehingga kepastian hukum kepada para pihak sulit tercapai.

\section{B. Permasalahan :}

1. Bagaimana sanksi hukum apabila ada salah satu pihak melakukan wanprestasi dalam perjanjian usaha waralaba online tersebut?

2. Bagaimana bentuk wanprestasi dalam perjanjian waralaba tersebut?

\section{Pembahasan}

\section{Sanksi hukum terhadap pihak melakukan wanprestasi dalam perjanjian waralaba online}

Pada umumnya perjanjian dibuat secara tertulis antara para pihak yang terlibat dalam perjanjian waralaba, namun ada pula perjanjian dibuat secara lisan 
dimana subjek dan objek perjanjian hanya dapat diyakini oleh para pihak yang membuat perjanjian. Perjanjian secara lisan tidak diatur secara spesifik dalam KUHPerdata maupun dalam peraturan perundang-undangan lainnya sehingga pengaturan perjanjian lisan hanya mengikuti pengaturan perjanjian pada umumnya yang terdapat dalam KUHPerdata (Pasal 1320 KUHP Perdata jo. Pasal 1338 ayat 1 KUHPerdata).

Menurut Martin dalam buku Darmawan Budi Suseno menyebutkan perjanjian waralaba harus secara tepat menggambarkan janji-janji yang dibuat dan harus adil, serta pada saat yang bersamaan menjamin bahwa ada kontrak yang cukup melindungi integritas sitem. ${ }^{6}$ Dengan demikian jika perjanjian waralaba online yang dibuat tanpa perjanjian tertulis, maka sangat mungkin untuk terjadi wanprestasi dalam pelaksanaanya sehingga salah satu pihak pasti dirugikan.

Permasalahan mengenai wanprestasi tidak bisaterlepas dari masalah "pernyataan lalai" (ingebrekke stelling) dan "kelalaian" (verzuim). Adapun menurut M. Yahya Harahap pengertian yang umum tentang "wanprestasi" adalah pelaksanaan kewajiban yang tidak tepat pada waktunya atau dilakukan tidak menurut selayaknya. $^{7}$

Bentuk-bentuk wanprestasi yang dilakukan oleh para pihak dalam perjanjian waralaba, wanprestasi dari pihak penerima waralaba dapat berbentuk tidak membayar biaya waralaba tepat pada waktunya, melakukan hal-hal yang dilarang dilakukan penerima waralaba, melakukan pelayanan yang tidak sesuai dengan sistem waralaba dan lain-lain. Wanprestasi dari pihak pemberi waralaba dapat berbentuk tidak memberikan fasilitas sehingga sistem waralaba tidak berjalan dengan sebagaimana mestinya, tidak mau membantu penerima waralaba dalam kesulitan yang dihadapi ketika melakukan usaha waralaba dan lain-lain.

Dalam hal para pihak melakukan perbuatan wanprestasi dalam perjanjian waralaba online maka dalam KUHPerdata ada beberapa sanksi hukum yaitu:

1. Debitur diharuskan membayar ganti rugi.

\footnotetext{
${ }^{6}$ Darmawan Budi Suseno,SuksesUsaha waralaba, Cakrawala,Yogyakarta,2007,hlm.11

${ }^{7}$ M. Yahya Harahap..Segi-segi Hukum Perjanjian, Bandung: PT Alumni. 1986,hlm 60
} 
Dasar hukumnya Pasal 1243 Kitab Undang-Undang Hukum Perdata (KUHPer), berbunyi:

"Penggantian biaya, kerugian dan bunga karena tak dipenuhinya suatu perikatan mulai diwajibkan, bila debitur, walaupun telah dinyatakan Ialai, tetap Ialai untuk memenuhi perikatan itu, atau jika sesuatu yang harus diberikan atau dilakukannya hanya dapat diberikan atau dilakukannya dalam waktu yang melampaui waktu yang telah ditentukan".

2. Kreditur dapat minta pembatalan perjanjian melalui pengadilan.

Dasar hukumnya Pasal 1266 KUHPer, berbunyi:

"Syarat batal dianggap selalu dicantumkan dalam persetujuan yang timbal balik, andaikata salah satu pihak tidak memenuhi kewajibannya. Dalam hal demikian persetujuan tidak batal demi hukum, tetapi pembatalan harus dimintakan kepada Pengadilan.

Permintaan ini juga harus dilakukan, meskipun syarat batal mengenai tidak dipenuhinya kewajiban dinyatakan di dalam persetujuan. Jika syarat batal tidak dinyatakan dalam persetujuan, maka Hakim dengan melihat keadaan, atas permintaan tergugat, leluasa memberikan suatu jangka waktu untuk memenuhi kewajiban, tetapi jangka waktu itu tidak boleh lebih dan satu bulan.”

3. Kreditur dapat minta pemenuhan perjanjian, atau pemenuhan perjanjian disertai ganti rugi dan pembatalan perjanjian dengan ganti rugi.

Dasar hukumnya Pasal 1267 KUHPerdata, berbunyi:

"Pihak yang terhadapnya perikatan tidak dipenuhi, dapat memilih; memaksa pihak yang lain untuk memenuhi persetujuan, jika hal itu masih dapat dilakukan, atau menuntut pembatalan persetujuan, dengan penggantian biaya, kerugian dan bunga."

Selain itu perbuatan wanprestasi dapat juga dipidana berdasarkan Pasal 378 Kitab Undang-Undang Hukum Pidana(“KUHP”) tentang penipuan dan Pasal 28 ayat (1) UU ITE tentang menyebarkan berita bohong dan menyesatkan yang mengakibatkan kerugian konsumen dalam Transaksi Elektronik.

Bunyi selengkapnya Pasal 378 KUHP adalah sebagai berikut:

Barangsiapa dengan maksud untuk menguntungkan diri sendiri atau orang lain secara melawan hukum, dengan memakai nama palsu atau 
martabat palsu, dengan tipu muslihat, ataupun rangkaian kebohongan, menggerakkan orang lain untuk menyerahkan barang sesuatu kepadanya, atau supaya memberi hutang maupun menghapuskan piutang, diancam karena penipuan dengan pidana penjara paling lama empat tahun.

Bunyi selengkapnya Pasal 28 ayat (1) UU ITE adalah sebagai berikut:" Setiap Orang dengan sengaja, dan tanpa hak menyebarkan berita bohong dan menyesatkan yang mengakibatkan kerugian konsumen dalam Transaksi Elektronik.

Terhadap pelanggaran Pasal 28 ayat (1) UU ITE sanksi hukum berupa pidana sebagaimana diatur dalam Pasal 45A ayat (1) UU 19/2016, yakni:

Setiap Orang yang dengan sengaja dan tanpa hak menyebarkan berita bohong dan menyesatkan yang mengakibatkan kerugian konsumen dalam Transaksi Elektronik sebagaimana dimaksud dalam Pasal 28 ayat (1) dipidana dengan pidana penjara paling lama 6 (enam) tahun dan/atau denda paling banyak Rp1.000.000.000,00 (satu miliar rupiah).

\section{Bentuk Wanprestasi Dalam Perjanjian Waralaba}

Dalam pelaksanaan perjanjian franchise atau waralaba akan ada kemungkinan terjadi wanprestasi. Wanprestasi ini terjadi jika salah satu pihak tidak melaksanakan kewajiban sebagaimana tertera dalam perjanjian waralaba. Jika karena adanya wanprestasi tersebut menyebabkan kerugian di pihak lain maka pihak yang dirugikan tersebut dapat menuntut kepada pihak yang melakukan wanprestasi untuk memenuhi prestasinya.

Permasalahan mengenai wanprestasi tidak bisaterlepas dari masalah "pernyataan lalai" (ingebrekke stelling) dan "kelalaian" (verzuim). Adapun menurut M. Yahya Harahap pengertian yang umum tentang "wanprestasi” adalah pelaksanaan kewajiban yang tidak tepat pada waktunya atau dilakukan tidak menurut selayaknya. ${ }^{8}$

Dalam perjanjian waralaba wanprestasi dapat dilakukan oleh pihak pemberi waralaba (franchisor) maupun pihak penerima waralaba (franchisee).

\footnotetext{
${ }^{8}$ Ibid
} 
Adapun bentuk wanprestasi yang dilakukan oleh pihak franchisor antara lain: tidak melakukan pembinaan manajemen kepada pihak franchisee, sedangkan wanprestasi dari pihak franchisee dapat berupa tidak membayar fee, melakukan pelayanan yang tidak sesuai dengan ketentuan yang diatur dalam perjanjian waralaba.

\section{Penutup}

\section{Kesimpulan}

a. Sanksi hukum terhadap pihak melakukan wanprestasi dalam perjanjian waralaba online

Dalam hal para pihak melakukan perbuatan wanprestasi dalam perjanjian waralaba online maka dalam KUHPerdata ada beberapa sanksi hukum yaitu:

a. Debitur diharuskan membayar ganti rugi.

Dasar hukumnya Pasal 1243 Kitab Undang-Undang Hukum Perdata (KUHPer), berbunyi:

"Penggantian biaya, kerugian dan bunga karena tak dipenuhinya suatu perikatan mulai diwajibkan, bila debitur, walaupun telah dinyatakan Ialai, tetap Ialai untuk memenuhi perikatan itu, atau jika sesuatu yang harus diberikan atau dilakukannya hanya dapat diberikan atau dilakukannya dalam waktu yang melampaui waktu yang telah ditentukan".

b. Kreditur dapat minta pembatalan perjanjian melalui pengadilan.

Dasar hukumnya Pasal 1266 KUHPer, berbunyi:“ Syarat batal dianggap selalu dicantumkan dalam persetujuan yang timbal balik, andaikata salah satu pihak tidak memenuhi kewajibannya. Dalam hal demikian persetujuan tidak batal demi hukum, tetapi pembatalan harus dimintakan kepada Pengadilan.

Permintaan ini juga harus dilakukan, meskipun syarat batal mengenai tidak dipenuhinya kewajiban dinyatakan di dalam persetujuan. Jika syarat batal tidak dinyatakan dalam persetujuan, maka Hakim dengan melihat keadaan, atas permintaan tergugat, leluasa memberikan suatu jangka waktu untuk memenuhi kewajiban, tetapi jangka waktu itu tidak boleh lebih dan satu bulan.” 
c. Kreditur dapat minta pemenuhan perjanjian, atau pemenuhan perjanjian disertai ganti rugi dan pembatalan perjanjian dengan ganti rugi.

Dasar hukumnya Pasal 1267 KUHPerdata, berbunyi:

"Pihak yang terhadapnya perikatan tidak dipenuhi, dapat memilih; memaksa pihak yang lain untuk memenuhi persetujuan, jika hal itu masih dapat dilakukan, atau menuntut pembatalan persetujuan, dengan penggantian biaya, kerugian dan bunga."

Selain itu perbuatan wanprestasi dapat juga dipidana berdasarkan Pasal 378 Kitab Undang-Undang Hukum Pidana(“KUHP”) tentang penipuan dan Pasal 28 ayat (1) UU ITE tentang menyebarkan berita bohong dan menyesatkan yang mengakibatkan kerugian konsumen dalam Transaksi Elektronik.

Bunyi selengkapnya Pasal 378 KUHP adalah sebagai berikut:

Barangsiapa dengan maksud untuk menguntungkan diri sendiri atau orang lain secara melawan hukum, dengan memakai nama palsu atau martabat palsu, dengan tipu muslihat, ataupun rangkaian kebohongan, menggerakkan orang lain untuk menyerahkan barang sesuatu kepadanya, atau supaya memberi hutang maupun menghapuskan piutang, diancam karena penipuan dengan pidana penjara paling lama empat tahun.

Bunyi selengkapnya Pasal 28 ayat (1) UU ITE adalah sebagai berikut:" Setiap Orang dengan sengaja, dan tanpa hak menyebarkan berita bohong dan menyesatkan yang mengakibatkan kerugian konsumen dalam Transaksi Elektronik.

Terhadap pelanggaran Pasal 28 ayat (1) UU ITE sanksi hukum berupa pidana sebagaimana diatur dalam Pasal 45A ayat (1) UU 19/2016, yakni:

Setiap Orang yang dengan sengaja dan tanpa hak menyebarkan berita bohong dan menyesatkan yang mengakibatkan kerugian konsumen dalam Transaksi Elektronik sebagaimana dimaksud dalam Pasal 28 ayat (1) dipidana dengan pidana penjara paling lama 6 (enam) tahun dan/atau denda paling banyak Rp1.000.000.000,00 (satu miliar rupiah). 


\section{b. Bentuk Wanprestasi Dalam Perjanjian Waralaba}

Dalam perjanjian waralaba wanprestasi dapat dilakukan oleh pihak pemberi waralaba (franchisor) maupun pihak penerima waralaba (franchisee).Adapun bentuk wanprestasi yang dilakukan oleh pihak franchisor antara lain: tidak melakukan pembinaan manajemen kepada pihak franchisee, sedangkan wanprestasi dari pihak franchisee dapat berupa tidak membayar fee, melakukan pelayanan yang tidak sesuai dengan ketentuan yang diatur dalam perjanjian waralaba.

\section{Saran-Saran}

1. Mengenai ketentuan pertanggungjawaban para pihak dalam perjanjian waralaba ada baiknya apabila diatur dalam pasal tersendiri agar lebih jelas lagi, sehingga peryanggungjawaban para pihak yang diberikan dapat maksimal, termasuk di dalamnya perlindungan hukum bagi para pihak bila terjadi wanprestasi

2. Pihak pemberi waralaba seharusnya menyeleksi secara ketat calon pewaralabanya sebelum menyetujui permohonan perjanjian dari penerima waralaba.

\section{DAFTAR PUSTAKA}

Az,Nasution Konsumen Dan Hukum,:Pustaka Sinar Harapan, Jakarta, 1999

Agus Raharjo, Cybercrime: Pemahaman dan Upaya Pencegahan Kejahatan Berteknologi, PT. Citra Aditya Bakti, Bandung, 2002

Akifa P. Nayla, Komplet Akuntansi Untuk UKM dan Waralaba, Laksana, Yogyakarta ,2014

Darmawan Budi Suseno,SuksesUsaha waralaba,Cakrawala,Yogyakarta,2007

M. Yahya Harahap..Segi-segi Hukum Perjanjian, Bandung: PT Alumni. 1986 